\title{
First chromosomal study of Mantophasmatodea: Karyotype of Karoophasma biedouwense (Austrophasmatidae)
}

\author{
Dorota LACHOWSKA-CIERLIK ${ }^{1}$, ANNA MARYAŃSKA-NADACHOWSKA², VALENTINA KUZNETSOVA ${ }^{3}$ \\ and MIKE PICKER ${ }^{4}$ \\ ${ }^{1}$ Institute of Zoology, Jagiellonian University, Cracow, Poland; e-mail: dorota.lachowska-cierlik@uj.edu.pl \\ ${ }^{2}$ Institute of Systematic and Evolution of Animals, PAS, Cracow, Poland; e-mail: maryanska@isez.pan.krakow.pl \\ ${ }^{3}$ Zoological Institute Russian Academy of Sciences, St. Petersburg, Russia; e-mail: valentina_kuznetsova@yahoo.com \\ ${ }^{4}$ Department of Biological Sciences, University of Cape Town, Rondebosch, Cape Town, South Africa; \\ e-mail: mike.picker@uct.ac.za
}

Key words. Mantophasmatodea, Karoophasma biedouwense, FISH, heterochromatin, heelwalkers, meiosis, ribosomal genes, sex determination system, telomeres

\begin{abstract}
We have investigated for the first time the chromosomes of Karoophasma biedouwense, a species belonging to the Mantophasmatodea, a recently discovered order of carnivorous insects. Our study has revealed that males of this species display testes with numerous seminal tubes (follicles), as in other Polyneoptera, and short tubular seminal vesicles embedded in a utricular gland. The karyotype consists of $2 \mathrm{n}=12 \mathrm{~A}+\mathrm{X}$ monocentric and biarmed, meta/submetacentric chromosomes (fundamental number of arms: $\mathrm{FN}$ $=26$ ) with blocks of heterochromatin around centromeres. The autosomes are classified into two size groups, one represented by a single, very large pair of autosomes, the other by five smaller pairs which constitute a continuous series gradually decreasing in size. Among "monocentric" orders of Polyneoptera, K. biedouwense shares its low chromosome number, $2 \mathrm{n}=13$, as also found with some Orthoptera (Acridoidea, Grylloidea, Gryllacridoidea). Male meiosis is of the classical pre-reductional type and the X(0) sex determination system is probably an ancestral state. Use of FISH along with an 18S rDNA probe revealed multiple ribosomal clusters, which most likely represent an apomorphic condition. We identified the ancestral insect telomeric sequence (TTAGG) in the terminal areas of the chromosomes. Currently available data on the polyneopteran orders putatively related to Mantophasmatodea showed a wide variability of cytogenetic characteristics within and between them. The only character allowing some tentative inference to be made on the ancestry of $K$. biedouwense is its low chromosome number, the karyotypic pattern so far unreported for the Polyneoptera except in certain Orthoptera.
\end{abstract}

\section{INTRODUCTION}

Mantophasmatodea is the most recently discovered insect order. These carnivorous insects (heelwalkers, rock crawlers or gladiators) were first described from Eocene Baltic amber fossils (Zompro, 2001), whilst amazingly, living specimens were actually found in Southern Africa at the turn of this century (Klass et al., 2002; Picker et al., 2002). Subsequent studies focussed on their morphology, behaviour, development, reproductive biology, genetics, taxonomy, systematics and phylogenetic relationships. Mantophasmatodea clearly fall within Polyneoptera (Gorochov, 2004; Huang et al., 2008; Roth et al., 2014). The sister group relationship of Mantophasmatodea were long considered controversial due to the paucity of morphological apomorphies and contradictions in various molecular analyses (Klass, 2007). Based on the morphology of the exoskeleton, male and female genitalia and antennae, they were considered as the sister group of Dictyoptera (Klass et al., 2003). This was supported by the mode of elongation of their antennae (Hockman et al., 2009). Other morphological studies placed the Mantophasmatodea close to the Orthoptera (Zompro, 2005) or Grylloblattodea (Arillo \& Engel, 2006, Wipfler et al., 2015). The ultrastructure of spermatozoa indicated a close relationship with Mantodea
(Dallai et al., 2003). According to DNA sequencing of the mitochondrial genome, Mantophasmatodea appeared as a sister group to Phasmatodea (Cameron et al., 2006; Plazzi et al., 2011). Gorochov (2004) hypothesized that Mantophasmatodea are living fossils, the descendants of the Triassic order Titanoptera (Mesotitanina) and suggested a close relationship to both the Orthoptera (grasshoppers and crickets) and Phasmatodea (stick insects). The unique development of the neuroendocrine capa-neurons in the central nervous system was described as a synapomorphy of Mantophasmatodea + Grylloblattodea (Predel et al., 2012). This clade was also recovered in the phylogenetic study based on a secondary structure model of the complete 28S rRNAs (Wang et al., 2013) and thoracic morphology (Wipfler, 2015). All these data from multiple sources have supported the unification of Mantophasmatodea + Grylloblattodea $=$ Notoptera, and confirmed that it represents one of the major lineages of the "lower Neoptera" (Terry \& Whiting, 2005, Wipfler et al., 2014). Mantophasmatodea currently comprises 19 described extant and 5 extinct species, with at least five more undescribed species (Buder \& Klass, 2013).

In contrast to the extensive morphological and molecular studies, the chromosomes of Mantophasmatodea have nev- 
er been explored. The study of the karyotype provides useful diagnostic characters for morphologically conservative species and has become an important tool for describing and delimiting new taxa of insects (e.g. Lukhtanov et al., 2008; Lachowska et al., 2009; Angus, 2010; MaryanskaNadachowska et al., 2012; Golub et al., 2014; Grozeva et al., 2014).

In the present paper, we describe the male karyotype and meiosis in the South African "gladiator" species, Karoophasma biedouwense Klass, Picker, Damgaard, van Noort \& Tojo, 2003 (Mantophasmatodea: Austrophasmatidae). Specifically, we analysed the location of ribosomal genes and molecular organization of telomeres in this species by using fluorescence in situ hybridization (FISH) along with $18 \mathrm{~S}$ rDNA and (TTAGG) $)_{n}$ telomeric probes. FISH is a method of choice for the physical mapping of repetitive DNA sequences, thereby enabling the characterization of the chromosomal complement. The aim of this study was to assess whether the cytogenetic features addressed confirm the affinity of $K$. biedouwense with other closely related Polyneoptera taxa.

\section{MATERIAL AND METHODS}

\section{Slide preparation}

Six adult male $K$. biedouwense were collected on 2/09/2011 from the Clanwilliam district of the Western Cape Province, South Africa $\left(32^{\circ} 04^{\prime} 27.63^{\prime \prime} \mathrm{S}, 19^{\circ} 05^{\prime} 37.13^{\prime \prime} \mathrm{E}\right)$. Abdomens of insects were cut off and fixed in Carnoy's solution, a mixture of $96 \%$ alcohol and glacial acetic acid $(3: 1)$, and stored at $-20^{\circ} \mathrm{C}$ until used. Testes were dissected, testicular follicles separated, and chromosomal preparations then made by squashing follicles in $45 \%$ acetic acid under a glass cover slip, followed by freezing on a block of dry ice. The coverslips were taken off with a razor blade and preparations were air-dried. Prior to staining, karyotypes were examined by phase contrast microscopy.

\section{Chromosome staining/banding techniques}

C-banding was performed as described in Sumner (1972). In brief, the preparations were treated at room temperature with $0.2 \mathrm{~N} \mathrm{HCl}$ for $20 \mathrm{~min}$ after this at $60^{\circ} \mathrm{C}$ with a saturated solution of barium hydroxide, $\mathrm{Ba}(\mathrm{OH})_{2}$ for periods 6 min. After washing in distilled water, slides were incubated in $2 \times \mathrm{SSC}$ at $60^{\circ} \mathrm{C}$ for 60 $\mathrm{min}$, and then stained in a $5 \%$ Giemsa solution for $10 \mathrm{~min}$. Fluorochrome staining with DAPI (4'-6'-diamidino-2-phenylindole) specific for the AT base pairs of the DNA and the GC-specific $\mathrm{CMA}_{3}$ (chromomycin $\mathrm{A}_{3}$ ) was done according to Donlon \& Magenis (1983) and Schweizer (1976) respectively. The C-banded preparations (omitting Giemsa treatment) were stained first with $\mathrm{CMA}_{3}(0.4 \mu \mathrm{g} / \mathrm{ml})$ for $25 \mathrm{~min}$ and then with DAPI $(0.4 \mu \mathrm{g} / \mathrm{ml})$ for $5 \mathrm{~min}$. After staining, the preparations were rinsed in McIlvaine buffer, $\mathrm{pH} 7$ (0.2 M disodium hydrogen phosphate and $0.1 \mathrm{M}$ citric acid), and mounted in an antifade medium (700 $\mu$ l glycerol, $300 \mu 10$ mM McIlvaine buffer, $\mathrm{pH} 7,10$ mg N-propyl gallate).

\section{Fluorescence in situ hybridization (FISH)}

The 18S rDNA probe was PCR amplified from the genomic DNA of the firebug, Pyrrhocoris apterus (L.) (Heteroptera: Pyrrhocoridae) and labelled with biotin-11-dUTP (Roche Diagnostics $\mathrm{GmbH}$, Mannheim, Germany) using primers and PCR conditions described in Grozeva et al. (2014). The (TTAGG) telomere probe was generated by non-template PCR and labelled with Rhodamine-5-dUTP (GeneCraft, Köln, Germany). FISH was performed as described in Grozeva et al. (2014). Chromosome prep- arations were treated with $100 \mu \mathrm{g} / \mathrm{ml}$ RNaseA, incubated in $5 \mathrm{mg} /$ $\mathrm{ml}$ pepsin in $0.01 \mathrm{M} \mathrm{HCl}$ to remove excessive amounts of RNAs and proteins. After pretreatment, the chromosomes were hybridized with a mixture containing about $100 \mathrm{ng}$ of labelled probes and $10 \mu \mathrm{g}$ of sonicated salmon-sperm DNA (Sigma-Aldrich, St. Louis, MO, USA). The $18 \mathrm{~S}$ rDNA probe was detected with $5 \mu \mathrm{g} /$ ml NeutrAvidin-FITC (Invitrogen, Carlsbad, California, USA). Chromosomes were mounted in a ProLong Gold antifade reagent with DAPI (Invitrogen) as described in Grozeva et al. (2014) and covered with a glass coverslip.

\section{Microscopy and image processing}

Examination of Giemsa-stained slides was performed using a Nikon Eclipse E400 light microscope at $1000 \times$ magnification. Micrographs were taken using a Nikon DS-U1 camera. Fluorescent preparations were examined using a Leica DM $6000 \mathrm{~B}$ microscope at $100 \times$ objective and images taken using a Leica DFC 345 FX camera and Leica Application Suite 3.7 software with an Image Overlay module (Leica Microsystems Wetzlar GmbH, Germany). The filter sets applied were A, L5, N21 (Leica Microsystems, Wetzlar, Germany).

\section{Preservation of samples}

The remaining tissues (fixed gonads) and chromosome slides are preserved in the Institute of Systematic and Evolution of Animals, Polish Academy of Sciences (Kraków).

\section{RESULTS}

\section{Male reproductive system}

The gonads in a mature male of $K$. biedouwense are located between the second and seventh abdominal segments and extend over four segments. They consist of paired, elongated testes, each containing numerous longitudinally arranged sperm tubes or follicles invested in a peritoneal sheath. The testes are covered by a sheet of fatty tissue. The numerous follicles could not be counted. The follicles were found to open separately into the sperm duct or vas deferens which expanded posteriorly to form a short, tubular sperm storage organ or seminal vesicle. Tubular paired accessory glands were formed from diverticula of the vasa deferentia, forming a utricular gland (Fig. 1).

\section{Male karyotype: $2 \mathrm{n}=\mathbf{1 2 A}+\mathrm{X} ; \mathrm{FN}=\mathbf{2 6}$}

The diploid chromosome number of $K$. biedouwense males is $2 n=13$. This number of chromosomes was found in 15 examined mitotic metaphase/prometaphase complements obtained from five different males. According to the

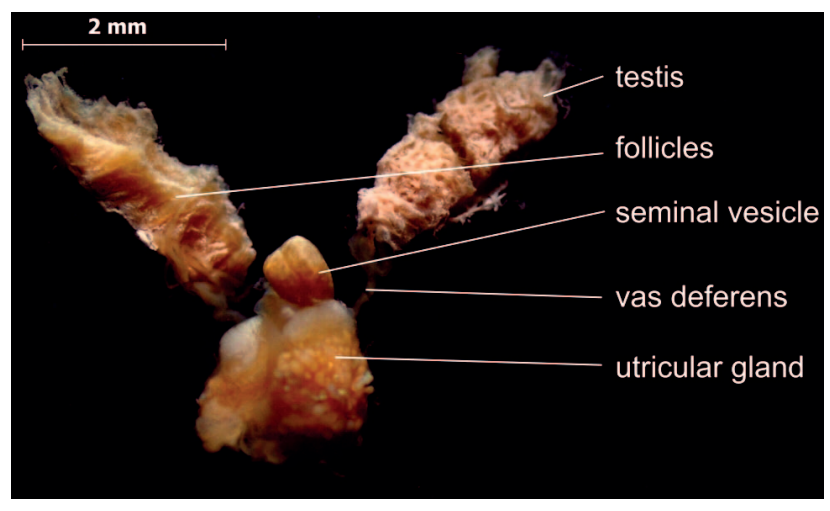

Fig. 1. Male reproductive system of $K$. biedouwense. Testicles sheathed with fatty deposits, partially obscuring follicles. 

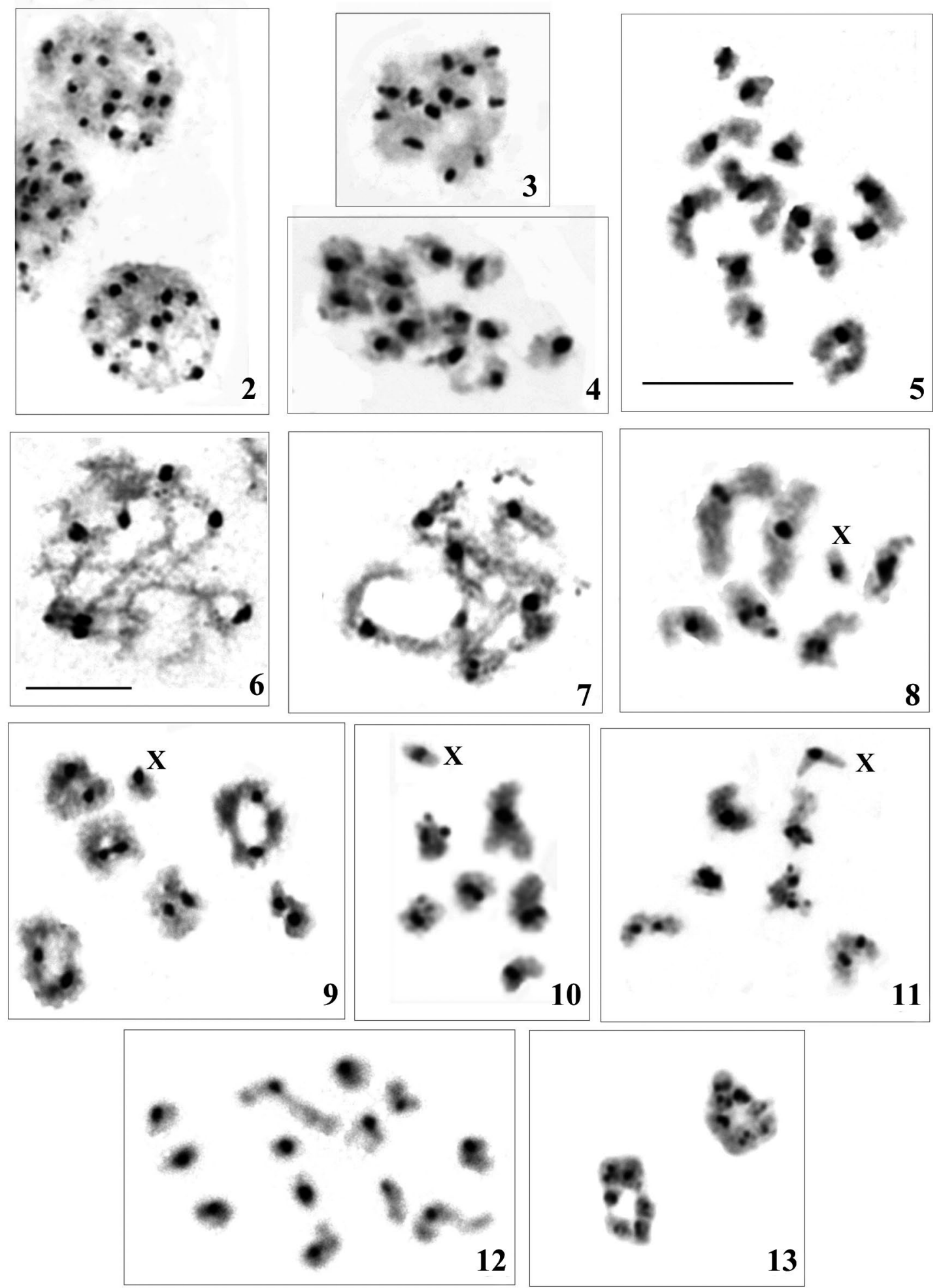

Figs 2-13. Mitotic and meiotic C-banded chromosomes of males of K. biedouwense. 2-5 - mitosis: 2 - early prophase; 3 - late prophase; 4 - prometaphase; 5 - metaphase. 6-13- meiosis: 6 - pachytene; 7 - early diplotene; 8 - diplotene; 9 - diakinesis; 10 metaphase I; 11 - early anaphase I; 12 - anaphase I; 13 - two daughter metaphases II, $\mathrm{n}=7$ and $\mathrm{n}=6$. Scale bars $=10 \mu \mathrm{m}$ (scales valid for Figs $2-5$ and 6-13, respectively).

position of centromere, all the chromosomes are distinctly biarmed, metacentric or submetacentric. Autosomes gradually decrease in size, whilst the $\mathrm{X}$ chromosome is difficult to identify at mitotic metaphases (Figs 2-5).

During pachytene, the chromosomes were seen to become individualized (Fig. 6). At diplotene, shortening of chromosomes occurred, and they appeared as bivalents with homologues lying parallel and showing no trace of chiasmata between them (Figs 7-8). However, at the beginning of diakinesis, the chiasmata began to be visible. These were invariably located terminally: three or four ring-shaped bivalents contained two chiasmata each, while 

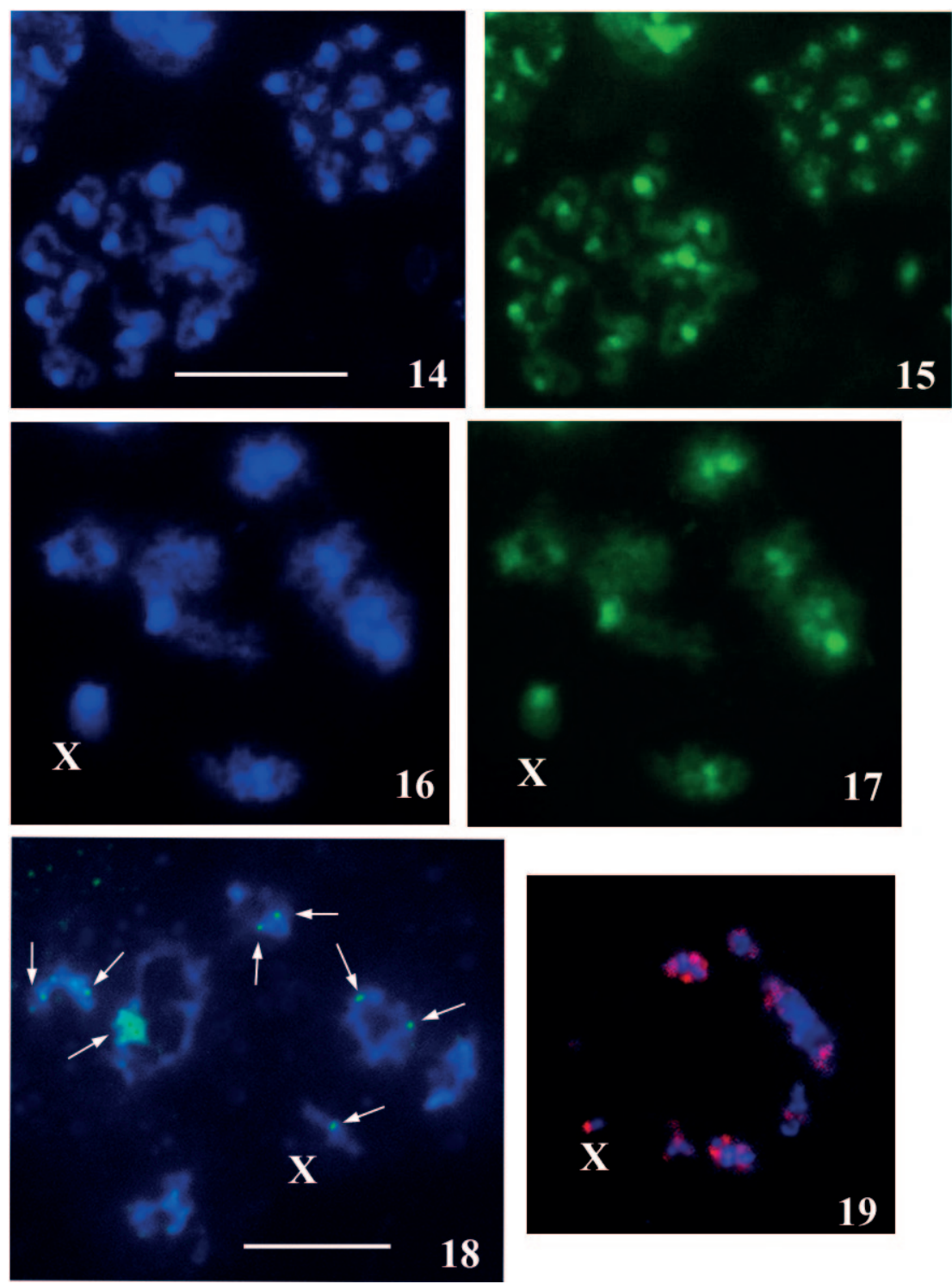

Figs 14-19. Fluorescent images of mitotic and meiotic chromosomes of males of $K$. biedouwense. 14-15 - mitotic prometaphase: DAPI-staining (14) and CMA3-staining (15). 16-17 - diplotene: DAPI-staining (16) and CMA3-staining (17). 18 - FISH with 18S ribosomal DNA probe: diakinesis, arrows indicate rDNA hybridization signals. 19 - FISH with (TTAGG) ${ }_{n}$ telomere probe: metaphase I. $\mathrm{X}$ - the sex chromosome. Scale bars $=10 \mu \mathrm{m}$ (scales valid for Figs 14 and 15-19, respectively).

each of the remaining bivalents had one chiasma (Fig. 9). At first metaphase (MI), bivalents were strongly shortened, and the sex univalent tended to be located at the periphery of the plate (Fig. 10). The first meiotic division seemed to proceed directly to meiosis II without going through interkinesis. As a result of anaphase I (AI), two daughter second metaphase (MII) cells formed, with $n=6 \mathrm{~A}$ and $\mathrm{n}=$ $6 \mathrm{~A}+\mathrm{X}$, respectively (Figs 11-13).

C-banding revealed distinct blocks of heterochromatin in all chromosomes in mitotic nuclei and during all meiotic stages (Figs 2-13). These blocks were large and of similar size, and were exclusively restricted to the pericentromeric regions, thus allowing recognition of chromosome morphology. C-heterochromatin was successively labelled with both DAPI and $\mathrm{CMA}_{3}$, indicating an equal content of AT and GC base pairs (Figs 14-17).
FISH with the 18S rDNA probe revealed a huge cluster of rDNA in the largest bivalent and small, clearly visible signals on three bivalents and on the X chromosome; $18 \mathrm{~S}$ rDNA sites were found at of both terminal and interstitial locations (Fig. 18). The exact number of sites was difficult to identify because of poor staining of the chromosomes available for the analysis. Fig. 19 demonstrates an attempt to use FISH with the (TTAGG) ${ }_{n}$ telomere probe. Although the image obtained was of fairly poor resolution, diakinetic bivalents still showed typically labelled terminal areas, indicative of the presence of this telomeric nucleotide sequence in the chromosomes of $K$. biedouwense.

\section{DISCUSSION}

We investigated the chromosomes of the recently discovered insect order Mantophasmatodea for the first time using the South African species, Karoophasma biedouwense. 
The study revealed that the testes have numerous seminal tubes (follicles), whilst the chromosomes themselves have a monocentric morphology and the karyotype consisting of $2 \mathrm{n}=12 \mathrm{~A}+\mathrm{X}$ and biarmed, meta/submetacentric chromosomes. Male meiosis is of the classical pre-reductional type.

As aforementioned, the precise placement of Mantophasmatodea within Polyneoptera is still controversial and the interordinal relationships remain unclear, despite the varied approaches that have been used to determine sister group relationships. The following polyneopteran high-ranking taxa have all been considered as being sister to taxa to Mantophasmatodea: Dictyoptera (Blattodea: cockroaches, Mantodea: mantids, Phasmatodea: stick- and leaf-insects), Grylloblattodea (ice/rock crawlers) and Orthoptera.

In different insect groups there is usually a pair of testes, each consisting of a series of seminal follicles ranging in number from one to over 100 . Polyneoptera seem to differ from other higher level insect groups in that the males seemingly have testes represented by numerous follicles, this pattern being encountered within the Phasmatodea, Blattodea, Mantodea and Orthoptera (Matsuda, 1976), and now also for $K$. biedouwense. However, the shape of the seminal vesicles and accessory glands do not bear a resemblance to those of the grylloblattodean - Galloisiana nipponensis (Caudell \& King) (Baccetti, 1982).

The cytogenetics of these orders was comprehensively reviewed as early as 1970 (White, 1976 for most groups; Hewitt, 1979 for Orthoptera). However since then, not much new information has appeared. The exception is the order Orthoptera in which, the great majority of cytogenetic data refers to grasshoppers (Acridoidea), particularly the family Acrididae.

Monocentric chromosomes are known to be characteristic of all polyneopteran orders, with the exception of the Dermaptera and Zoraptera. The latter two orders display chromosomes of a holokinetic type (Kuznetsova et al., 2002; Lukhtanov \& Kuznetsova, 2010) tentatively suggesting a clade Zoraptera + Dermaptera as a sister group of all other polyneopteran orders. Terry \& Whiting (2005) on the basis of a molecular study placed the Zoraptera as a sister group of Dermaptera and referred to this clade as "Haplicercata". Our finding of monocentric chromosomes in $K$. biedouwense suggests that this chromosome morphology is characteristic of the Mantophasmatodea as a whole, but more detailed assessment of a greater range of genera is required to confirm this.

An $\mathrm{XX} / \mathrm{X}(0)$ sex chromosome system occurs in every polyneopteran order, being the predominant sex determination system of each and probably is the ancestral form of sex determination (Blackman, 1995). The other systems, i.e. $\mathrm{XY}$ and those with multiple $\mathrm{X}$ and $\mathrm{Y}$ chromosomes, are encountered in the groups under consideration but are considered derived and evolved on the base of the initial $\mathrm{XX} / \mathrm{X}(0)$ system due to subsequent chromosomal rearrangements. Thus, the $\mathrm{X}(0)$ system discovered in $K$. biedouwense must be regarded as an ancestral state.
The presently known chromosome numbers of Polyneoptera lie between $2 \mathrm{n}=8$ (Dermaptera, Orthoptera: Acrididae) to $2 \mathrm{n}=98$ (Isoptera) (White, 1976; Saez \& Perez-Mosquera, 1977; Hewitt, 1979). These groups seem, in general, to have high chromosome numbers. In the Phasmatodea, karyotype numbers vary from $2 \mathrm{n}=22$ to $2 \mathrm{n}=$ 54 in the diploid species (White, 1976; Scali et al., 2012; Myers et al., 2013). In Mantodea, the diploid chromosome numbers lie between 14 and 40 (White, 1976, del Cerro et al., 1998), while in Blattodea they fall between 15 and 75, and possibly even 79 (i.e. in Macropanesthia rhinoceros Saussure; Family Blaberidae) (White 1976; Maekawa \& Nalepa, 2011). In Grylloblattodea, the single species studied so far Galloisiana nipponensis from Japan was shown to have a karyotype $2 \mathrm{n}=30, \mathrm{XX} / \mathrm{XY}$ (Nakamura \& Kidata, 1955).

Orthoptera represent one of the most extensively investigated groups cytogenetically, with $2 \mathrm{n}=8$ as the lowest and $2 \mathrm{n}=52$ as the highest chromosome numbers detected. Much existing data are for the superfamilies Acridoidea $(2 \mathrm{n}=8-25$; modal number $2 \mathrm{n}=23)$ and Tettigonoidea $(2 \mathrm{n}=20-35$; modal number $2 \mathrm{n}=31)$ (White, 1976; Saez \& Pérez-Mosquera, 1977; Hewitt, 1979; WarchałowskaŚliwa, 1998). Less known are the karyotypes of Grylloidea $(2 \mathrm{n}=11-29)$ and Gryllacridoidea $(2 \mathrm{n}=11-52)$ (Hewitt, 1979). The highest variability of chromosome number was found in the latter group (Hewitt, 1979). As for other polyneopteran groups which are characterized by monocentric chromosomes, these show similarly high chromosome numbers. Within Isoptera (termites), the more evolved, i.e. "higher" groups are karyologically uniform with $2 \mathrm{n}=42$, while "lower" termites are more variable, with $2 \mathrm{n}$ ranging from 28 to 56 (Bergamaschi et al., 2007). Very little is known about the karyotypes of the small order Embioptera in which chromosome numbers lie between 19 and 23 (White, 1976; Hodson et al., 2014). Thus, among "monocentric" orders of Polyneoptera, K. biedouwense shares its low chromosome number, $2 \mathrm{n}=13$, only with Orthoptera.

In Polyneoptera the number of chiasmata is variable with the highest value recorded for some orthopteran species, while the most common are one or two chiasmata per bivalent. One to two terminal chiasmata are also present in $K$. biedouwense. It is known that the frequency of chiasmata is regulated not only by genetic but also by certain environmental factors (King, 1993).

The number and the chromosomal location of genes encoding ribosomal RNA (rDNA) are the important species characteristics. Such sites may be restricted to one chromosome pair or sometimes to all chromosomes of a species. Among Polyneoptera, rDNA loci were detected by FISH only in Orthoptera, and mostly they were found to be located near the centromeric regions. The number of chromosomes showing the presence of rDNA ranges in this group from 2 to 20 (Cabrero \& Camacho, 2008). In K. biedouwense almost all chromosomes bear rDNA loci at terminal and interstitial locations. In insects two loci (i.e. one for each homologue of a particular pair) bearing rDNA genes 
seem to be more common, indicative of some restrictions of high numbers of rDNA loci within species. For example, one or two chromosome pairs with the 5S rRNA gene were reported in a study of 29 grasshopper species from the family Acrididae (Cabral-de-Mello et al., 2011) and in almost all of the 94 species of true bugs (Hemiptera: Heteroptera) (Grozeva et al., 2014). Thus, the multiple ribosomal clusters found in $K$. biedouwense most likely represent a derived (apomorphic) condition.

The telomeric sequence (TTAGG) identified in $K$. biedouwense, is known to be characteristic of the majority of insect groups and is considered to be ancestral for Insecta and even for Arthropoda as a whole (Frydrychová et al., 2004; Vitková et al., 2005; Lukhtanov \& Kuznetsova, 2010; Grzywacz et al., 2011). This insect telomeric motif has been reported for all species studied so far within the Polyneoptera (i.e. Isoptera, Plecoptera, Blattodea, Mantodea, and Orthoptera), the only exception being the Dermaptera (Frydrychová et al., 2004; Warchałowska-Śliwa et al., 2013).

In conclusion, we have provided the first information of the karyotype of a species member of the order Mantophasmatodea. A brief overview of the currently available data on the polyneopteran orders putatively identified as sister groups to mantophasmatids showed a wide variability of cytogenetic characteristics within and between them. Even though K. biedouwense, the subject of our own particular study, shares some similarities with one or other representative of these orders, the chromosomal evidence available is clearly still insufficient to support any postulated relationship of Mantophasmatodea with other Polyneoptera orders. The only character allowing some tentative inference is a low chromosome number as found in K. biedouwense, a karyotypic pattern so far never reported for members of the Polyneoptera with the exception of the Orthoptera.

ACKNOWLEDGEMENTS. FISH experiments were performed with the support of the state research project no. 01201451099 and a grant from RFBR no. 14-04-01051 (given to VK). We thank B. Anokhin for his kind technical help with the application of FISH as here used and H.D. Loxdale for his helpful editorial suggestions for improving the manuscript.

\section{REFERENCES}

Angus R.B. 2010: Boreonectes gen. n., a new genus for the Stictotarsus griseistriatus (De Geer) group of sibling species (Coleoptera: Dytiscidae) with additional karyosystematic data on the group. - Compar. Cytogen. 4: 123-131.

Arillo A. \& Engel M.S. 2006: Rock crawlers in Baltic amber (Notoptera: Mantophasmatodea). - Am. Mus. Nov. 3539: $1-10$.

BACCETtI B. 1982: The spermatozoon of Arthropoda. XXXII. Galiosiana nipponensis (Caudel et King) (Grylloblattodea). In Ando H. (ed.): Biology of the Notoptera. Kashiyo-Insatsu, Nagano, pp. 71-78.

Bergamaschi S., Dawes-Gromadzki T., Scali V., Marini M. \& Mantovani B. 2007: Karyology, mitochondrial DNA and the phylogeny of Australian termites. - Chromos. Res. 15: 735753.

Blackman R.L. 1995: Sex Determination in Insects. Insect Reproduction. CRC Press, Boca Raton, FL, 255 pp.
Buder G. \& Klass K.D. 2013: The morphology of tarsal processes in Mantophasmatodea. - Dt. Entomol. Z. 60: 5-23.

Cabral-de-Mello D.C., Cabrero J., López-León M.D. \& CamaCHO J.P.M. 2011: Evolutionary dynamics of 5S rDNA location in acridid grasshoppers and its relationship with $\mathrm{H} 3$ histone gene and 45S rDNA location. - Genetica 139: 921-931.

CABRero J. \& CAMACHO J.P.M. 2008: Location and expression of ribosomal RNA genes in grasshoppers: Abundance of silent and cryptic loci. - Chromos. Res. 16: 595-607.

CAmeron S.L., Barker S.C. \& Whiting M.F. 2006: Mitochondrial geneomics and the new insect order Mantophasmatodea. - Mol. Phylogenet. Evol. 38: 274-279.

del Cerro A.L., Cuñado N. \& Santos J.L. 1998: Synaptonemal complex analysis of the $\mathrm{X}_{1} \mathrm{X}_{2} \mathrm{Y}$ trivalent in Mantis religiosa $\mathrm{L}$. males: inferences on the origin and maintenance of the sexdetermining mechanism. - Chromos. Res. 6: 5-11.

Dallai R., Frati F., Lupetti P. \& Adis J. 2003: Sperm ultrastructure of Mantophasma zephyra (Insecta: Mantophasmatodea). - Zoomorphology 122: 67-76.

Donlon T.A. \& MAGEnIS R.E. 1983: Methyl green is a substitute for distamycin A in the formation of distamycin A/DAPI Cbands. - Human Genet. 65: 144-146.

Frydrychová R., Grossmann P., Trubač P., VítKová M. \& Marec F. 2004: Phylogenetic distribution of TTAGG telomeric repeats in insects. - Genome 47: 163-178.

Golub N.V., Kuznetsova V.G. \& Rakitov R.A. 2014: First karyotype data on the family Myerslopiidae (Hemiptera, Auchenorrhyncha, Cicadomorpha). - Compar. Cytogen. 8: 293-300.

Gorochov A.V. 2004: Primitive Titanoptera and early evolution of Polyneoptera. - Meetings in Memory of N.A. Cholodkovsky 57(1): 1-54 [in Russian].

Grozeva S., Anokhin B. \& Kuznetsova V.G. 2014: Bed bugs (Hemiptera). In Sharachov I. (ed.): Protocols for Cytogenetic Mapping of Arthropod Genomes. CRC press, Taylor \& Francis, Boca Raton, pp. 285-326.

Grzywacz B., Maryańska-Nadachowska A., Chobanov D.P., KaramaYShEVA T. \& WarchąOWSKA-ŚLIWA E. 2011: Comparative analysis of the location of rDNA in the Palaearctic bushcricket genus Isophya (Orthoptera: Tettigoniidae: Phaneropterinae). - Eur. J. Entomol. 108: 509-517.

HewitT G.M. 1979: Animal Cytogenetics. Orthoptera - Grasshoppers and Crickets. Vol. 3: Insecta 1. Gebrüder Borntraeger, Berlin, Stuttgart, $170 \mathrm{pp}$.

Hockman D., Picker M.D., Klass K.D. \& Pretorius L. 2009: Postembryonic development of the unique antenna of Mantophasmatodea (Insecta). - Arthropod Struct. Devel. 38: 125133.

Hodson A.M., CooK S.E., Edgerly J.S. \& Miller K.B. 2014: Parthenogenetic and sexual species within the Haploembia solieri species complex (Embioptera: Oligotomidae) found in California. - Insect Syst. Evol. 45: 93-113.

Huang D., Nel A. \& Zompro O. 2008: Mantophasmatodea now in the Jurassic. - Naturwissenschaften 95: 947-952.

KING M. 1993: Species Evolution - The Role of Chromosome Change. Cambridge University Press, Cambridge, 366 pp.

KLass K.D. 2007: Die Stammesgeschichte der Hexapoden: eine kritische Diskussion neuerer Daten und Hypothesen. - Denisia 20: 413-450.

Klass K.D., Zompro O., Kristensen N.P \& Adis J. 2002: Mantophasmatodea: a new insect order with extant members in the afrotropics. - Science 296: 1456-1459.

Klass K.D., Picker M.D., Damgaard J., Van Noort S. \& Tojo K. 2003: The taxonomy, genitalic morphology, and phylogenetic relationships of South African Mantophasmatodea (Insecta). —Entomol. Abh. 61: 3-67. 
Kuznetsova V., Nokkala S. \& Shcherbakov D. 2002: Karyotype, reproductive organs, and pattern of gametogenesis in Zorotypus hubbardi Caudell (Insecta: Zoraptera, Zorotypidae), with discussion on relationships of the order. - Can. J. Zool. 80: $1047-1054$

Lachowska D., Rożek M. \& Holecova M. 2009: Chromosomal similarities and differences among three sibling species of the Acalles echinatus group (Coleoptera, Curculionidae, Cryptorhynchinae). - Zootaxa 1985: 63-68.

LukhtANov V.A. \& KuzNetsova V.G. 2010: What genes and chromosomes say about the origin and evolution of insects and other arthropods. - Russ. J. Genet. 46: 1115-1121.

Lukhtanov V.A., Shapoval N.A. \& Dantchenko A.V. 2008: Agrodiaetus shahkuhensis sp. n. (Lepidoptera, Lycaenidae), a cryptic species from Iran discovered by using molecular and chromosomal markers. - Compar. Cytogen. 2: 99-114.

MAEKAWA K. \& NALEPA C.A. 2011: Biogeography and phylogeny of wood-feeding cockroaches in the genus Cryptocercus. Insects Sci. 2: 354-368.

Maryańska-Nadachowska A., Kuznetsova V.G., LachowsKa D. \& Drosopoulos S. 2012: Mediterranean species of the spittlebug genus Philaenus: modes of chromosome evolution. $-J$. Insect Sci. 12: 1-17.

Matsuda R. 1976: Morphology and Evolution of the Insect Abdomen (With Special Reference to Developmental Patterns and their Bearings upon Systematics). International Series in Pure and Applied Biology (Zoology Division). Vol. 56. Pergamon Press, Oxford, New York, Toronto, Sydney, Paris, Frankfurt, $534 \mathrm{pp}$

Myers S.S, Trewick S.A. \& Morgan-Richards M. 2013: Multiple lines of evidence suggest mosaic polyploidy in the hybrid parthenogenetic stick insect lineage Acanthoxyla. - Insect Conserv. Divers. 6: 537-548.

NAKAMURA K. \& KidATA J.I. 1955: Chromosomes of some orthopteroid insects, with reference to sex-chromosomes. - Cytologia 20: 119-132.

Picker M.D., Colville J.F. \& VAn Noort S. 2002: Mantophasmatodea now in South Africa. - Science 297: 1475.

Plazzi F., Ricci A. \& Passamonti M. 2011: The mitochondrial genome of Bacillus stick insects (Phasmatodea) and the phylogeny of orthopteroid insects. - Mol. Phylogenet. Evol. 58: 304-316.

Predel R., Neuperts S., Huetteroth W., Kahnt J., Waidelich D. \& Rотн S. 2012: Peptidomics-based phylogeny and biogeography of Mantophasmatodea (Hexapoda). - Syst. Biol. 61: 609-629.

Roth S., Molina J. \& Predel R. 2014: Biodiversity, ecology, and behaviour of the recently discovered insect order Mantophasmatodea. - Front. Zool. 11: 70.
Saez F.A. \& Pérez-Mosquera G. 1977: Structure, behaviour and evolution of the chromosomes of Dichroplus silveiraguidoi (Orthoptera: Acrididae). — Genetica 47: 105-113.

Scali V., Milani L. \& Passamonti M. 2012: Revision of the stick insect genus Leptynia: description of new taxa, speciation mechanism and phylogeography. - Contr. Zool. 81: 25-42.

SCHWEIZER D. 1976: Reverse fluorescent chromosome banding with chromomycin and DAPI. - Chromosoma 58: 307-324.

SuMNER A.T. 1972: A simple technique for demonstrating centromeric heterochromatin. - Exp. Cell Res. 75: 304-306.

Terry M.D. \& Whiting M.F. 2005: Mantophasmatodea and phylogeny of the lower neopterous insects. - Cladistics 21: 240-257.

Vítková M., Král J., Traut W., Zrzavý J. \& Marec F. 2005: The evolutionary origin of insect telomeric repeats (TTAGG $)$. Chromos. Res. 3: 145-156.

Wang Y., Engel M.S., Rafael J.K., Dang K., Wu H., Wang Y., XIE Q. \& BU W. 2013: A unique box in 28S rRNA is shared by the enigmatic insect order Zoraptera and Dictyoptera. - PLoS One 8(1): e53679.

WarChaŁOWSKA-ŚLIWA E. 1998: Karyotype characteristics of katydid orthopterans (Ensifera, Tettigoniidae) and remarks on their evolution at different taxonomic levels. - Folia Biol. (Kraków) 46: 143-176.

WarchalowsKa-Śliwa E., GrZyWacz B., MaryańSKa-NadachowsKa A., Karamysheva T., Chobanov D.P. \& Heller K.G. 2013: Cytogenetic variability among Bradyporinae species (Orthoptera: Tettigoniidae). - Eur. J. Entomol. 110: 1-12.

Whiтe M. 1976: Animal Cytogenetics. Vol. 3: Insecta 2. Gebrüder Borntraeger, Berlin, Stuttgart, 75 pp.

Wipfler B., Bai M., Schoville S., Dallai R., Uchifune T., Machida R., CuI Y. \& Beutel R.G. 2014: Ice crawlers (Grylloblattodea) - the history of the investigation of a highly unusual group of insects. - J. Insect Biodiv. 2: 1-25.

Wipfler B., Klug R., Ge S.-Q., Bai M., Göbbels J., Yang X.-K. \& HöRnSCHEMEYER T. 2015: The thorax of Mantophasmatodea, the morphology of flightlessness and the evolution of the neopteran insects. - Cladistics 21: 50-70.

Zompro O. 2001: The Phasmatodea and Raptophasma n. gen., Orthopetra incertae sedis in Baltic amber (Insecta: Orthoptera). - Mitt. Geol.-Paläontol. Inst. Univ. Hamburg 85: 229-261.

ZомрRо O. 2005: Inter- and intra-ordinal relationships of the Mantophasmatodea, with comments on the phylogeny of polyneopteran orders (Insecta: Polyneoptera). - Mitt. Geol.Paläontol. Inst. Univ. Hamburg 89: 85-116.

Received April 20, 2015; revised and accepted July 3, 2015 Prepublished online September 22, 2015 